\title{
Teaching NeuroImages: Kearns-Sayre syndrome
}

Michael T.B. Nguyen, MD, Jonathan Micieli, MD, FRCSC, and Edward Margolin, MD, FRCSC, DABO

Neurology ${ }^{\circledR}$ 2019;92:e519-e520. doi:10.1212/WNL.0000000000006861
Correspondence

Dr. Margolin

edmargolin@gmail.com

Figure 1 Ptosis and ophthalmoplegia
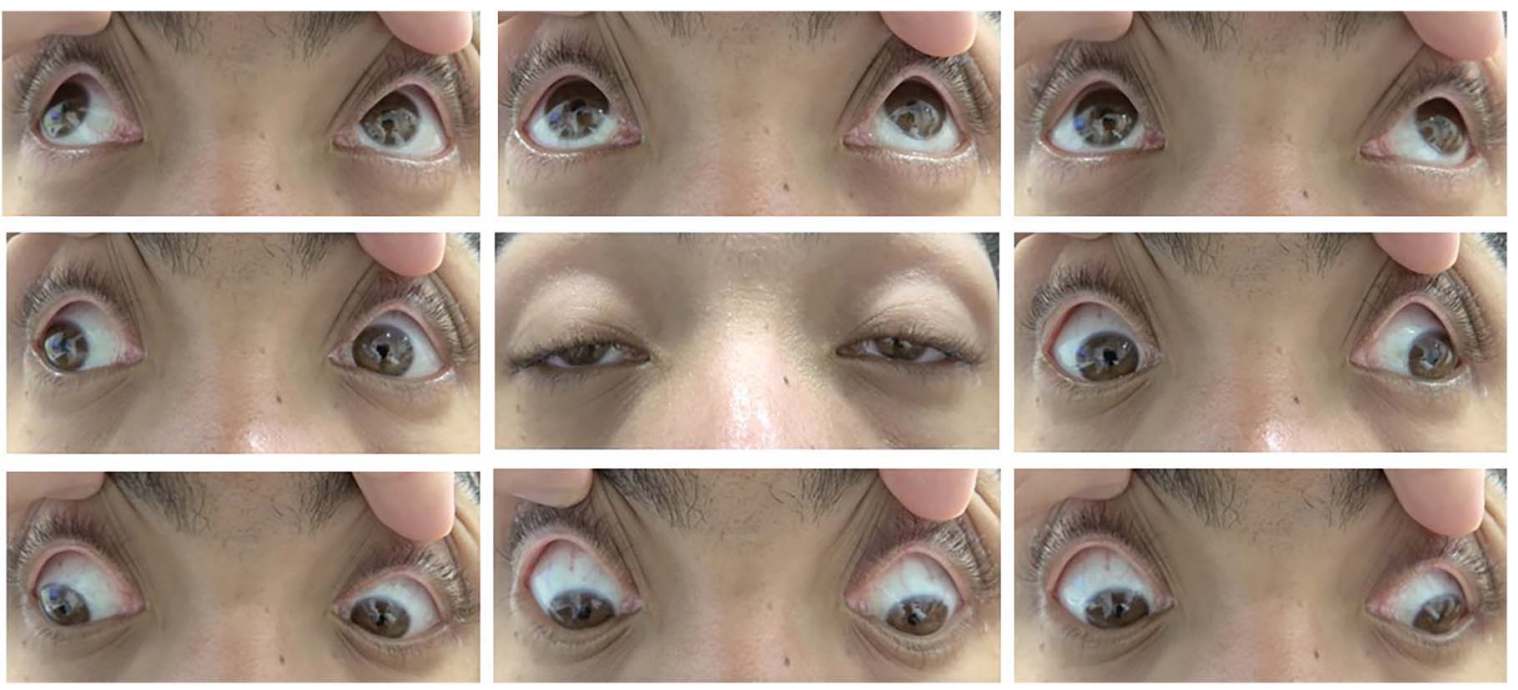

Photographs of eye movement demonstrate severe bilateral ptosis and mild diffuse ophthalmoplegia in all directions of attempted gaze.

A 19-year-old man presented 6 months postimplantation of permanent pacemaker for complete heart block with bilateral nonfatigable symmetric ptosis, diminished levator superioris function, and symmetric ophthalmoplegia (figure 1). Funduscopy revealed bilateral pigmentary retinopathy (figure 2). Skeletal muscle biopsy revealed presence of ragged-red fibers, consistent with Kearns-Sayre syndrome. This mitochondrial disorder is characterized by the triad of onset before age 20, chronic progressive external ophthalmoplegia, and pigmentary retinopathy. Other findings can include complete heart block, cerebellar ataxia, deafness, and endocrinopathies. CSF folate levels should be measured and supplemented if low. There is no definitive treatment but annual surveillance for comorbidities is required. ${ }^{1,2}$

\section{Study funding}

No targeted funding reported.

\section{Disclosure}

The authors report no disclosures relevant to the manuscript. Go to Neurology.org/ $\mathrm{N}$ for full disclosures.
MORE ONLINE

$\rightarrow$ Teaching slides

links.lww.com/WNL/

A796 
Figure 2 Pigmentary retinopathy

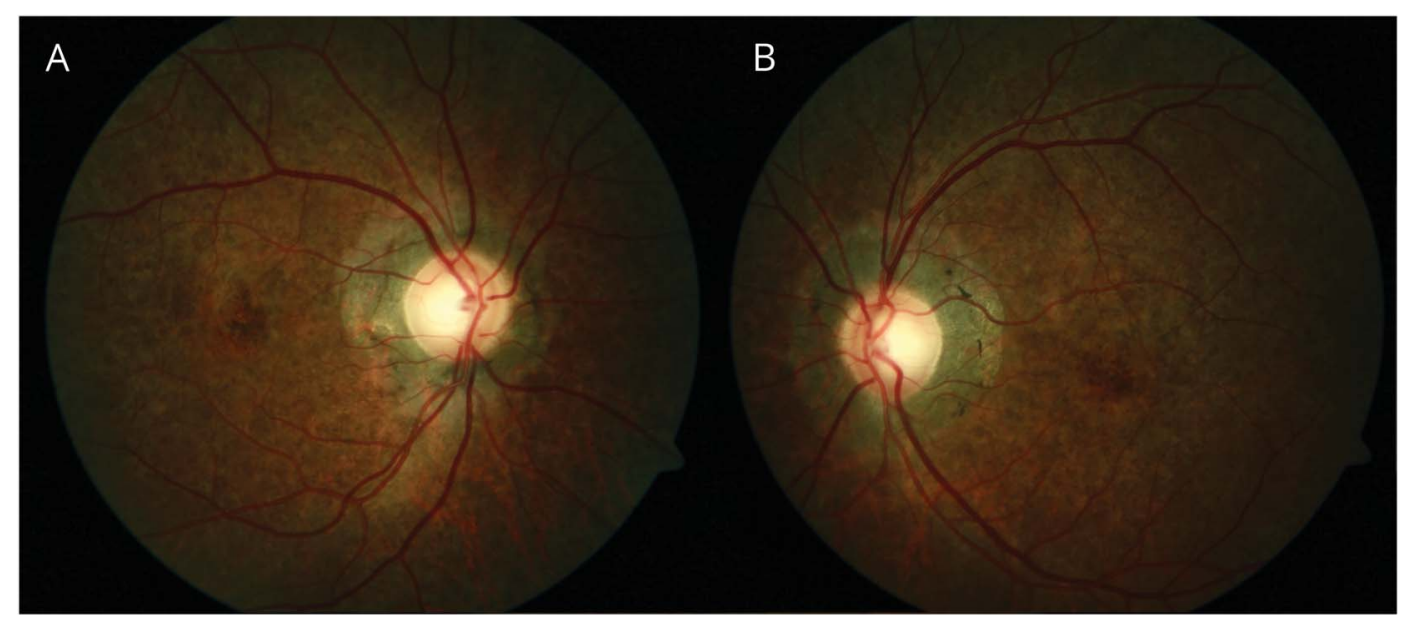

Fundus examination of right (A) and left eye (B) shows bilateral pigmentary retinopathy. There is diffuse depigmentation of the retinal pigment epithelium in a salt-and-pepper pattern of pigment clumping and involvement of the peripapillary zone.

\section{Appendix Authors}

\begin{tabular}{llll}
\hline Name & Location & Role & Contribution \\
\hline $\begin{array}{l}\text { Michael T.B. } \\
\text { Nguyen, MD }\end{array}$ & $\begin{array}{l}\text { University } \\
\text { of Toronto }\end{array}$ & Author & Drafted manuscript \\
\hline $\begin{array}{l}\text { Jonathan A. } \\
\text { Micieli, MD, }\end{array}$ & $\begin{array}{l}\text { University } \\
\text { of Toronto }\end{array}$ & Author & Revised manuscript \\
$\begin{array}{l}\text { FRCSC } \\
\text { Edward }\end{array}$ & University & Author & $\begin{array}{l}\text { Conceptualization of case } \\
\text { Margolin, MD, } \\
\text { FRCSC, DABO }\end{array}$ \\
\hline
\end{tabular}

\section{References}

1. Kearns TP, Sayre GP. Retinitis pigmentosa, external ophthalmoplegia, and complete heart block. Arch Ophthalmol 1958;60:280-289.

2. Shemesh A, Margolin E. Kearns Sayre syndrome. In: StatPearls [Internet]. Treasure Island, FL: StatPearls Publishing; 2018. Available at: ncbi.nlm.nih.gov/books/ NBK482341/. Accessed June 9, 2018. 


\title{
Neurology
}

\author{
Teaching NeuroImages: Kearns-Sayre syndrome \\ Michael T.B. Nguyen, Jonathan Micieli and Edward Margolin \\ Neurology 2019;92;e519-e520 \\ DOI 10.1212/WNL.0000000000006861
}

This information is current as of January 28, 2019

\section{Updated Information \& Services}

References

Subspecialty Collections

Permissions \& Licensing

Reprints including high resolution figures, can be found at: http://n.neurology.org/content/92/5/e519.full

This article cites 1 articles, 0 of which you can access for free at: http://n.neurology.org/content/92/5/e519.full\#ref-list-1

This article, along with others on similar topics, appears in the following collection(s):

All Neuro-ophthalmology

http://n.neurology.org/cgi/collection/all_neuroophthalmology Eyelids

http://n.neurology.org/cgi/collection/eyelids

Mitochondrial disorders

http://n.neurology.org/cgi/collection/mitochondrial_disorders

Ocular motility

http://n.neurology.org/cgi/collection/ocular_motility

Retina

http://n.neurology.org/cgi/collection/retina

Information about reproducing this article in parts (figures,tables) or in its entirety can be found online at:

http://www.neurology.org/about/about_the_journal\#permissions

Information about ordering reprints can be found online:

http://n.neurology.org/subscribers/advertise

Neurology ${ }^{\circledR}$ is the official journal of the American Academy of Neurology. Published continuously since 1951, it is now a weekly with 48 issues per year. Copyright (O 2019 American Academy of Neurology. All rights reserved. Print ISSN: 0028-3878. Online ISSN: 1526-632X.

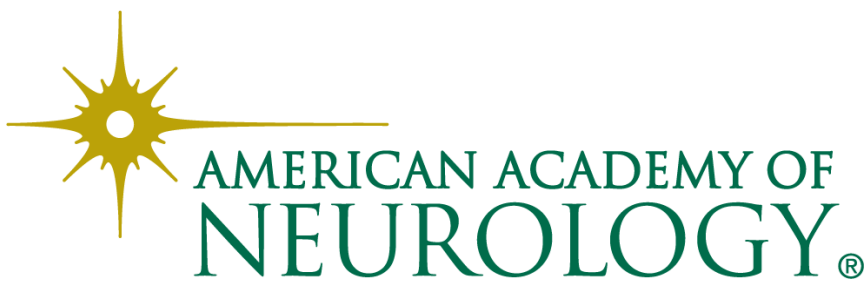

